\title{
The Effectiveness of Inquiry Learning Model in Improving Prospective Teachers' Metacognition Knowledge and Metacognition Awareness
}

\author{
Muhammad Asy'ari \\ Sport and Health Department, IKIP Mataram, Indonesia, \\ muhammadasyari@ikipmataram.ac.id \\ Muhamad Ikhsan \\ Sport and Health Department, IKIP Mataram, Indonesia,
} muhamadikhsan@ikipmataram.ac.id

Muhali

Dr., Chemistry Department, IKIP Mataram, Indonesia, muhali@ikipmataram.ac.id

This study aimed at (1) evaluating the effectiveness of inquiry learning model; (2) consistency of inquiry learning model impact; and (3) identifying differences of consistency of inquiry learning model impact in improving the prospective teachers' metacognition knowledge and metacognition awareness in learning about fluid. This study was a weak-experimental research since there was no control class. There were three experimental classes in order to find consistency within the results of the study, which was also designed as one-group pretest-posttest protocol. Samples in this study were 90 students, which were distributed into three groups by using saturated sampling technique. Metacognition knowledge tests consisted of 20 items asking about description, while Metacognition Awareness Inventory (MAI) was used to collect data about metacognition awareness. Results showed that metacognition knowledge and metacognition awareness of samples from three groups were significantly varied after being engaged in learning $(\mathrm{p}<$ $0.05)$. The impact of applying inquiry learning model was not significantly varied ( $>$ > 0.05), but only on samples' metacognition awareness among Group B and Group C. The inquiry learning model was proven effective in increasing samples' metacognition knowledge and metacognition awareness in learning about fluid. However, the impact was inconsistent in all three experimental groups.

Keywords: effectiveness, inquiry learning model, metacognition, metacognition knowledge, metacognition awareness

Citation: Asy'ari, M., Ikhsan, M., \& Muhali. (2019). The Effectiveness of Inquiry Learning Model in Improving Prospective Teachers' Metacognition Knowledge and Metacognition Awareness. International Journal of Instruction, 12(2), 455-470. https://doi.org/10.29333/iji.2019.12229a 


\section{INTRODUCTION}

Metacognition is an important goal and focus of education in Indonesia and throughout the world (Thomas, 2012). In line with this statement, Margaret (2002) states that metacognition is very important in learning considering the knowledge of cognitive processes may lead students to decide and select strategies to improve their cognitive performances. Metacognition as one of 21st century skills is very essential to be taught in order to produce independent students, which is the ultimate goal of learning and the key of acknowledging the development of twenty-first century science education (Thomas, 2012). Metacognition is very important in learning process since it is something that must be practiced before, during, and after learning (Ya-Hui, 2012). Metacognition, in broader sense, covers the basic knowledge of individuals to recognize the basic knowledge related to varied cognitive tasks and knowledge about strategies in completing various cognitive tasks by practicing good planning, providing alternative solutions, analyzing, synthesizing, and evaluating processes whenever new problems encounter (Tosun \& Senocak, 2013).

Metacognition is basic characteristic of human's cognition (Muhali, 2018) that is simply defined as thinking about thinking (McCormick, 2003; Lai, 2011) by heading through an evaluation of conscious thinking process. Metacognition is an ability of individuals to organize and monitor input, as well as to store, search, and retrieve it from the content of memory (Flavell, 1971). It is activated through four components of action and interaction, i.e. (1) metacognition knowledge; (2) metacognition experiences; (3) goals or tasks; and (4) actions or strategies (Flavell, 1979). Moreover, metacognition is an activity of thinking about one's own thoughts and others, monitoring and regulating one's own way of thinking (Kluwe, 1982; Aiken, 1982; Senomoglu, 2009), which is based on differences between knowledge and regulation of cognition (Schraw et al., 2012).

In general, experts on metacognition argue that metacognition is high order cognition of cognition (Veenman, 2012; Pintich et al., 2000; Meijer et al., 2006) that controls cognition system and at the same time becoming part of metacognition itself (Veenman et al., 2006). Metacognition functions as a set of self-instructions to regulate task performance, while cognition is a prerequisite condition to enable self-instruction (Sternberg, 1990). Veenman et al. (2004); Veenman and Spaans (2005) state that there is a correlation between metacognition and cognition, in which metacognition contributes more than cognition $(17 \%>10 \%)$ in relation to encourage variation in learning by students of different age and background with different tasks and domains. Weinert and Kluwe (1987) explain that while cognition focuses on solving problems, metacognition more focuses with the process of solving the problems, knowledge on how to use thoughts and strategies, knowledge on one's learning capacity (in terms of size), and types of strategies to be used. Its implication is that one's adequate metacognition skill may give positive impact for his/her low cognitive ability.

Cavanough and Perlmutter (1982) state that metacognition is only related to one's declarative knowledge regarding his/her memory capacity and strategies affecting the memory process. Furthermore, Schraw and Mosman (1995) explain that declarative knowledge must be supported by conditional knowledge in relation to 'when' a problem 
solving strategies can be applied properly and the goal of solving the problem. Students often do not know about selected strategy, reasons of choosing the strategy, and when to use it. These facts give impact to a situation in which a conditional knowledge does not necessarily guarantee a well implemented strategy. Conditional knowledge is a prerequisite condition, but it is not enough to make students to be proficient in metacognition skills (Veenman, 2012). Based on these circumstances, Zohar and David (2008: 2009) state that knowledge of metastrategy is needed, which becomes procedural knowledge and conditional knowledge in teaching metacognition to students.

Definition of metacognition by Paris and Winograd (1990) captures two important features, i.e. self-assessment and self-management of cognition. Self-assessment is student's personal reflection regarding the state of his/her own knowledge and abilities, and his/her affective condition that deals with knowledge, ability, motivation, and characteristics as a student. These reflections respond some questions, including "what does student know, how does student think, when and why should one apply certain strategy of knowledge". Self-assessment according to some experts is described as regulation of one's cognition or relevant metacognition awareness with activities that may help someone to control his mind and learning process (Schraw \& Moshman, 1995; Schraw, 2006; Schraw et al., 2012). Metacognition awareness has three core indicators in the cognitive regulation, i.e. planning, examination, and evaluation (Jakobs \& Paris, 1987; Kluwe, 1987). McCormick (2003) states that many adults appear to be more knowledgeable about their cognitions than children and teenagers. However, most adults cannot explain certain expertise and performance as well as their tendency to failure regarding the use of specific sources of knowledge when a frame spontaneously given. Experts state that adults tend to be weak in monitoring when facing real conditions (Pressley \& Harris, 2006), therefore, indicators, such as management of information and debugging, need to be considered (Schraw at al., 2012). Niedringhaus (2010) states that a student with metacognition awareness tends to have knowledge on how to think and to control his/her learning. Knowledge about how to think includes knowledge about learning preference, strength, weakness, as well as what knowledge to obtain and the best way to obtain it.

Applied instructional model to teach metacognition ability to students is inquiry learning model, which is an instructional model designed to expose students with scientific experience through questioning, constructing hypotheses as responses for questions, and testing hypotheses based on data in order to shape deep understanding on scientific methods, develop critical thinking, self-regulation, and comprehension on specific topics (Eggen \& Kauchak, 2012). Students are directed to construct a hypothesis before seeking evidence. Earlier than having the hypothesis, students are encouraged to clarify their prior knowledge (Lee, 2006). Inquiry learning model may improve students' critical thinking, logical reasoning, and problem solving in creative manner (Suardana et al., 2018; Fuad et al., 2017; Prayogi et al., 2018), which ultimately gives positive impacts to their learning outcomes (Kizkapan \& Bektas, 2017). Arends (2012) defines inquiry as an instructional method that aims at generating scientist to develop, understand, and apply new knowledge of various ideas through systematic questioning, hypothesis, and experiments for a new discovery. Furthermore, Hussain et al. (2011) 
define inquiry as an activity that involves observation, questioning, examining sources of information to confirm what has been known, planning an investigation, conducting an experiment, utilizing tools for data collection, analyzing and interpreting data, formulating an answer, elaboration, and prediction, and communicating obtained results.

This study aims at (1) evaluating the effectiveness of inquiry learning model to increase teacher-students' metacognition knowledge (declarative, procedural, and conditional knowledge) and metacognition awareness (declarative, procedural, conditional, planning, information management, monitoring, debugging, and evaluation) in learning about fluid; (2) finding the consistency of impact of inquiry learning model towards applied in three experimental classes; and (3) identifying different impact of applying inquiry learning model in three pilot classes in attempt to increase metacognition knowledge and awareness of prospective physics teacher-students at IKIP Mataram, Indonesia.

\section{METHOD}

\section{Population and Samples}

Population and sample of this study were 90 prospective student-teachers from three classes that took Fundamental of Physics I course at Faculty of Mathematics and Science Education IKIP Mataram, Indonesia. Sample selection was based on Goodwin's (2012) suggestion who stated that when population was less than 100, they were categorized as saturated samples.

\section{Instrument and Procedure}

This study was a weak-experimental study since there was no control class made as a comparison. There were only three experimental classes taken in an attempt to seek for consistency of results of the study, within one-group pre-test post-test design with $\mathrm{O} 1 \mathrm{X}$ O2 design (Fraenkel et al., 2012). This study involved three experimental groups, in which each class was given a pre-test $(\mathrm{O} 1)$ before students took part in learning about fluid. Test on knowledge about metacognition and questionnaire on metacognition awareness given to students were generated from indicators of these two variables as proposed by Schraw and Dennison (1994). Test towards metacognition knowledge consisted of 20 items of descriptive problems that had been declared as valid and reliable items in terms of its contents and constructs (score > 3.6; percentage of agreement $=97.3 \%$ for the content and $98.6 \%$ for the construct). The metacognition knowledge test was also empirically declared valid (Pearson Correlation > rtable) and reliable (Cronbach's alpha $=0.944)$ (Asy'ari et al., 2018). The questionnaire regarding metacognition awareness was taken from Metacognition Awareness Inventory (MAI) as suggested by Schraw and Dennison (1994), which was stated as generally consistent ( $\alpha$ Cronbach $=0.96)(\mathrm{Oz}, 2016$; Feiz, 2016). The inquiry learning model was further implemented in three experimental groups (X) after pre-test being given. By the end of treatments given, students from all groups were given post-test $(\mathrm{O} 2)$, which dealt with similar subjects and problems with those in pre-test $(\mathrm{O} 1)$. 


\section{Data analysis}

Metacognition knowledge and awareness of the subjects of this study were descriptively calculated using the following formula:

Final score $(\mathrm{K})=[($ Score obtained $/$ maximum item score $) \mathrm{x}$ maximum score $]$

Result scores were further converted into four categories, as follows: $\mathrm{K} \leq 1.33$ (poor); $1.33<\mathrm{K} 332.33$ (good enough); $2.33<\mathrm{K} \leq 3.33$ (good); and $3.33<\mathrm{K} \leq 4.00$ (very good). Alteration of scores in metacognition knowledge test and metacognition awareness were resulted through calculation of n-gain equation formula as suggested by (Hake, 1999):

$\mathrm{n}$-gain $=\left[\left(\right.\right.$ Score $_{\text {posttest }}-$ Score $\left._{\text {pretest }}\right) /\left(\right.$ Score $_{\text {maximum }}-$ Score $\left.\left._{\text {pretest }}\right)\right]$

Result after having $\mathrm{n}$-gain equation calculation was further converted into three categories: high (>0.70), moderate $(0.30-0.70)$, and low $(<0.30)$.

Inferential analysis was used to examine the effectiveness of inquiry learning model by viewing students' increase regarding metacognition knowledge and metacognition awareness in the implementation stage. Results of pre-test and post-test were further statistically analysed. Analysis regarding the significance within the increase result of pre-test and post-test was conducted after having prerequisite tests, i.e. data normality test and variance homogeneity test conducted by utilizing a software (IBM SPSS Statistics 23).

Test on normality of data (pre-test and post-test) was conducted by applying Kolmogorov-Smirnov $\mathrm{Z}$ one-sample test. Normally distributed data were further analysed using pair t-test (parametric), while Non-normally distributed ones were analysed using Wilcoxon test (non-parametric) in order to determine the increase of metacognition knowledge and metacognition awareness in teacher-students after being involved in inquiry learning model. In measuring the level of consistency up on the impact of implementing inquiry learning model towards students' metacognition knowledge and metacognition awareness, this study applied variant analysis (ANOVA). Method of examination depended on the results that were in accordance with assumptions generated in normality test and homogeneity test of variants of n-gain.

\section{FINDINGS}

Effectiveness and consistency of the impact within the implementation of inquiry learning model towards metacognition knowledge and metacognition awareness were analyzed descriptively by using n-gain formula proposed by Hake (1999) and inferential statistics. After applying Kolmogorov-Smirnov Z one-sample test, this study found normality of data collected through pre-test and post-test, as shown in Table 1. 
Table 1

Normality of Data Collected in Pre-Test and Post-Test Towards Students' Metacognition Knowledge and Metacognition Awareness From All Groups

\begin{tabular}{|c|c|c|c|c|c|c|c|c|c|c|}
\hline \multirow[b]{2}{*}{ Group } & \multirow[t]{2}{*}{ Test } & \multirow[t]{2}{*}{$\mathrm{N}$} & \multicolumn{4}{|c|}{ Metacognition knowledge } & \multicolumn{4}{|c|}{ Metacognition awareness } \\
\hline & & & Mean & $\begin{array}{l}\text { Std. } \\
\text { Deviation }\end{array}$ & $\begin{array}{l}\text { Asymp. } \\
\text { Sig. (2- } \\
\text { tailed) }\end{array}$ & Normality & Mean & $\begin{array}{l}\text { Std. } \\
\text { Deviation }\end{array}$ & $\begin{array}{l}\text { Asymp. } \\
\text { Sig. (2- } \\
\text { tailed) }\end{array}$ & Normality \\
\hline \multirow[t]{2}{*}{$\bar{A}$} & pre-test & 30 & 1.3993 & .08379 & .200 & yes & 1.6743 & .07333 & .011 & no \\
\hline & $\begin{array}{l}\text { post- } \\
\text { test }\end{array}$ & 30 & 3.9613 & .14202 & .200 & yes & 3.2490 & .09915 & .200 & yes \\
\hline \multirow[t]{2}{*}{ B } & pre-test & 30 & 1.3397 & .05512 & .149 & yes & 1.7080 & .07586 & .200 & yes \\
\hline & $\begin{array}{l}\text { post- } \\
\text { test }\end{array}$ & 30 & 3.7623 & .16286 & .200 & yes & 3.0837 & .15199 & .200 & yes \\
\hline \multirow[t]{2}{*}{$\mathrm{C}$} & pre-test & 30 & 1.3797 & .05916 & 200 & yes & 1.7167 & .07734 & .200 & yes \\
\hline & $\begin{array}{l}\text { post- } \\
\text { test }\end{array}$ & 30 & 3.6617 & .13689 & .151 & yes & 3.0867 & .07928 & .200 & yes \\
\hline
\end{tabular}

Table 1 shows the score of subjects' metacognition knowledge and metacognition awareness in pre-test and post-test are normally distributed, with an exception of subjects' metacognition awareness from Group A. Therefore, this study applied Wilcoxon test to analyze the impact of learning using inquiry models towards subjects in this group. Meanwhile, paired t-test was taken to data from Group B and C, in which data were found normally distributed.

Hence, results of pre-test, post-test, and n-gain calculation on metacognition knowledge of all subjects in every group were analysed using three indicators, i.e. (1) declarative knowledge (DK), (2) procedural knowledge (PK), and (3) conditional knowledge (CK). All data were collected in four class sessions towards three groups, as figured in Table 2.

Table 2

Results of Descriptive Analysis Towards Pre-Test, Post-Test, and N-Gain Based on Indicators of Metacognition Knowledge in All Groups

\begin{tabular}{|c|c|c|c|c|c|}
\hline \multirow{2}{*}{ Group } & \multirow{2}{*}{$\mathrm{N}$} & \multirow{2}{*}{ Scores } & \multicolumn{3}{|c|}{ Metacognition Knowledge Indicators } \\
\hline & & & DK & PK & $\mathrm{CK}$ \\
\hline \multirow{3}{*}{ A } & \multirow{3}{*}{30} & Pre-test & 1.39 & 1.39 & 1.42 \\
\hline & & Post-test & 4 & 3.93 & 3.96 \\
\hline & & n-gain & 0.72 & 0.70 & 0.71 \\
\hline \multirow{3}{*}{ B } & \multirow{3}{*}{30} & Pre-test & 1.14 & 1.57 & 1.5 \\
\hline & & Post-test & 3.78 & 3.78 & 3.73 \\
\hline & & n-gain & 0.68 & 0.64 & 0.64 \\
\hline \multirow{3}{*}{$\mathrm{C}$} & \multirow{3}{*}{30} & Pre-test & 1.38 & 1.39 & 1.37 \\
\hline & & Post-test & 3.63 & 3.7 & 3.66 \\
\hline & & n-gain & 0.62 & 0.64 & 0.63 \\
\hline
\end{tabular}

Table 2 presents the average scores of pre-test, post-test and n-gain that shows subjects' metacognition knowledge based on three types of knowledge, i.e. (1) declarative knowledge, (2) procedural knowledge, and (3) conditional knowledge. The effectiveness of inquiry learning model to improve teacher-students' metacognition knowledge is supported by the results of n-gain analysis, as shown in Table 2, in which n-gain was 
found in moderate category $(0.3<\mathrm{n}$-gain $<0.7)$. Metacognition knowledge of Group A subjects was found high $(>0.7)$, while those from Group B and C were categorized moderate $(0.3<\mathrm{n}$-gain $<0.7)$. Hence, it can be stated that inquiry learning model is effective to improve metacognition knowledge and awareness of prospective teachers from three experimental groups in this study.

Metacognition awareness is related to activities that help a person control his mind and learning. Metacognition awareness inventory (MAI) developed by Schraw and Dennison (1994) contains 8 aspects, i.e. (1) declarative knowledge (DK), (2) procedural knowledge (PK), (3) conditional knowledge (CK), (4) planning (P), (5) information management (IMS), (6) monitoring (M), (7) debugging (D), and (8) evaluating (E). MAI was applied in this study to collect data on prospective teachers' metacognition awareness. Results of pre-test, post-test, and n-gain of questionnaire on metacognition awareness based on MAI are briefly presented in Table 3.

Table 3

Results of Descriptive Analysis Towards Pre-Test, Post-Test, and N-Gain of Metacognition Awareness Indicators of All Groups

\begin{tabular}{|c|c|c|c|c|c|c|c|c|c|c|}
\hline \multirow{2}{*}{ Group } & \multirow{2}{*}{$\mathrm{N}$} & \multirow{2}{*}{ Scores } & \multicolumn{8}{|c|}{ Metacognition Awareness Indicators } \\
\hline & & & DK & PK & CK & $\mathrm{P}$ & IMS & M & $\mathrm{D}$ & $\mathrm{E}$ \\
\hline \multirow{3}{*}{ A } & \multirow{3}{*}{30} & Pre-test & 1.7 & 1.69 & 1.66 & 1.69 & 1.67 & 1.68 & 1.59 & 1.71 \\
\hline & & Post-test & 3.33 & 3.26 & 3.3 & 3.25 & 3.21 & 3.23 & 3.19 & 3.22 \\
\hline & & n-gain & 0.71 & 0.68 & 0.70 & 0.68 & 0.66 & 0.67 & 0.66 & 0.66 \\
\hline \multirow{3}{*}{ B } & \multirow{3}{*}{30} & Pre-test & 1.75 & 1.73 & 1.73 & 1.71 & 1.7 & 1.68 & 1.69 & 1.68 \\
\hline & & Post-test & 3.05 & 3.13 & 3.04 & 3.09 & 3.1 & 3.08 & 3.11 & 3.09 \\
\hline & & n-gain & 0.58 & 0.62 & 0.58 & 0.60 & 0.61 & 0.60 & 0.61 & 0.61 \\
\hline \multirow{3}{*}{$\mathrm{C}$} & \multirow{3}{*}{30} & Pre-test & 1.69 & 1.73 & 1.73 & 1.73 & 1.71 & 1.72 & 1.74 & 1.7 \\
\hline & & Post-test & 3.07 & 3.11 & 3.05 & 3.12 & 3.06 & 3.05 & 3.15 & 3.08 \\
\hline & & n-gain & 0.60 & 0.61 & 0.58 & 0.61 & 0.59 & 0.58 & 0.62 & 0.60 \\
\hline
\end{tabular}

Table 3 shows scores of prospective teachers' metacognition awareness in pre-test and post-test based on MAI during learning fluid in three experimental groups, in which all group members records increase at moderate level of n-gain $(0.68 ; 0.60$; and 0.60$)$ after engaged in learning using inquiry learning model. Based on these results, it can be stated that inquiry learning model is considered effective to improve prospective teachers' metacognition knowledge and metacognition awareness.

Table 4 and Table 5 show the results of the Wilcoxon test and paired t-test preceded with normality test on to prospective teachers' metacognition knowledge and metacognition awareness, which is based on results of pre-test and post-test, as shown in Table 1.

Table 4

The Wilcoxon Test Result on Prospective Teachers' Metacognition Awareness of Group A

\begin{tabular}{llll}
\hline & $\mathrm{N}$ & $\mathrm{z}$ & $\mathrm{p}$ \\
\hline Pre-test and post-test & 30 & -4.785 & .000 \\
\hline
\end{tabular}


Table 5

Results of Paired T-Test on Metacognition Knowledge and Metacognition Awareness of All Groups

\begin{tabular}{llllllllllll}
\hline & \multicolumn{3}{c}{ Metacognition knowledge } & \multicolumn{7}{c}{ Metacognition awareness } \\
\cline { 2 - 11 } Pair & $\mathrm{N}$ & Mean & $\begin{array}{l}\text { Std. } \\
\text { Error } \\
\text { Mean }\end{array}$ & $\mathrm{t}$ & $\mathrm{df}$ & $\mathrm{p}$ & Mean & $\begin{array}{l}\text { Std. } \\
\text { Error } \\
\text { Mean }\end{array}$ & $\mathrm{t}$ & $\mathrm{df}$ & $\mathrm{P}$ \\
\hline Pair 1 & 30 & 2.56200 & .02774 & 92.343 & 29 & .000 & Wilcoxon test & & \\
\hline Pair 2 & 30 & 2.42267 & .03284 & 73.767 & 29 & .000 & 1.37567 & .02675 & 51.427 & 29 & .000 \\
\hline Pair 3 & 30 & 2.28200 & .02685 & 84.999 & 29 & .000 & 1.37000 & .01613 & 84.926 & 29 & .000 \\
\hline
\end{tabular}

Table 4 shows that the $\mathrm{Z}$ value is of $-4,785$ within the level of significance value of $\mathrm{p}<$ .05. The result indicates that inquiry learning model has given an impact towards metacognition awareness of subjects in Group A. Hence, Table 5 shows that t-value of metacognition knowledge of subjects from three groups within degree of freedom ( $\mathrm{df}$ ) of 30, shown in sequence $(A-B-C): t=92,343 ; t=73,767 ; t=84,999$. Meanwhile, for metacognition awareness, the results are (in sequence) $t=51,427 ; t=84,927$ within the level of significance of all groups in terms of metacognition knowledge and metacognition awareness of $\mathrm{p}<.05$ (significant category).

ANOVA analysis was used to measure level of consistency in terms of the impact of applying the inquiry learning model towards the increase of prospective teachers' metacognition knowledge and metacognition awareness. This test was conducted after knowing the data were normally distributed and its homogeneous variants, as displayed in Table 6.

Table 6

Results of ANOVA Test to Metacognition Knowledge and Metacognition Awareness Of All Groups

\begin{tabular}{lllllll}
\hline n-gain all groups & & $\begin{array}{l}\text { Sum of } \\
\text { squares }\end{array}$ & df & $\begin{array}{l}\text { Mean } \\
\text { square }\end{array}$ & F & $\mathrm{p}$ \\
\hline Metacognition & Between Groups & .102 & 2 & .051 & 30.838 & .000 \\
knowledge & Within Groups & .144 & 87 & .002 & & \\
\cline { 2 - 7 } & Total & .247 & 89 & & & \\
\cline { 2 - 7 } Metacognition & Between Groups & .118 & 2 & .059 & 25.963 & .000 \\
awareness & Within Groups & .197 & 87 & .002 & & \\
\cline { 2 - 7 } & Total & .315 & 89 & & & \\
\hline
\end{tabular}

Table 6 shows that the score of significance (p) on prospective teachers' metacognition knowledge and metacognition awareness in learning fluid is lower than alpha of the test (0.05), so that the impact of inquiry learning model as an attempt to increase subjects' metacognition knowledge and awareness is significantly different in all three experimental groups $(\mathrm{p}<0.05)$. The LSD (Least Significant Different) test was then carried out to find out whether the differences in data of prospective teachers' metacognition knowledge and metacognition awareness were stated to be significantly different. The results of LSD test are presented in Table 7. 
Table 7

LSD Test Results on Subjects' Metacognition Knowledge and Metacognition Awareness

\begin{tabular}{|c|c|c|c|}
\hline \multirow{2}{*}{ Test (Class) } & \multirow{2}{*}{ Group (Class) } & Metacognition knowledge & Metacognition awareness \\
\hline & & $\mathrm{p}$ & $\mathrm{p}$ \\
\hline \multirow[t]{2}{*}{$\mathrm{A}$} & $\mathrm{B}$ & .000 & .000 \\
\hline & $\mathrm{C}$ & .000 & .000 \\
\hline \multirow[t]{2}{*}{ B } & A & .000 & .000 \\
\hline & $\mathrm{C}$ & .008 & 1.000 \\
\hline \multirow[t]{2}{*}{$\mathrm{C}$} & A & .000 & .000 \\
\hline & $\mathrm{B}$ & .008 & 1.000 \\
\hline
\end{tabular}

Table 7 shows the significance values $(\mathrm{p}<0.05)$ of all experimental groups. Hence, it can be stated that prospective teachers' metacognition knowledge is significantly different in all experimental groups after learning using inquiry learning model. On the other hand, subjects' metacognition awareness is significantly different between Group A and Group B ( $<<0.05)$ and between Group A and Group C ( $<<0.05)$. Therefore, Group B and Group C prospective teachers' metacognition awareness are not significantly different $(\mathrm{p}>0.05)$ at significance level of $5 \%$.

\section{DISCUSSION}

The results showed that prospective teachers' metacognition knowledge and metacognition awareness increased in all three experimental groups. These results indicate that the inquiry learning model has a significant impact on increasing the prospective teachers' metacognition knowledge and metacognition awareness in learning about fluid. The inquiry learning model focuses on process of thinking that builds experience by involving students actively in learning (Kuhlthau \& Todd, 2007). Inquiry learning model involves students in scientific learning processes like a scientist does, solving problems with observation, collecting data carefully and accurately (Stave, 2013) that allow students to have deeper understanding of the concepts being learned. Inquiry-based learning is a process of student engagement in learning, formulating problems, investigating extensively and then building understanding, interpretation and acquiring new knowledge to be applied towards different problems that may generate several types of action in solving problems (Yuliati et al., 2018). Inquiry learning processes are planned cautiously and monitored faultlessly, but it still equips and guides the students to experience freedom in their learning (Kuhlthau \& Todd. 2007), which provides assistances for students to develop high- order thinking skills through inquiry activities (Arends, 2012; Suardana et al., 2018; Artayasa et al., 2018).

All phases in inquiry learning model, such as formulating explanations and conclusions, as well as reflecting problem situations and using thinking process on similar problems enable students to monitor process of thinking, which is stated by Muhali (2018) as highly related to metacognition strategies. It is empirically stated to have significant impact towards the increase of students' metacognition awareness. Yusnaeni et al. (2017) state that metacognition strategies provide opportunities for students to monitor learning being conducted and to adapt the same strategy to overcome new problems as needed. Hence, main characteristics of inquiry learning model, including (1) an 
emphasis on searching and finding activities, (2) facilitating efforts to seek and find solutions of problems independently in order to uplift self-belief, and (3) developing ability to think systematically, logically, and critically, or to develop intellectual capacity to be component of mental processes (Jacobsen et al., 2009) enhance the effectiveness of inquiry learning model to improve higher-order thinking skills (Arends, 2012), which includes metacognition.

A study about inquiry-based learning and metacognition by Seraphin et al. (2012) argues that metacognition reflection cannot be separated from inquiry-based learning, which enhances students in developing better critical thinking. Sukaisih and Muhali (2014) report on the implementation of problem-solving learning model within inquiry as it basic can improve student's learning achievement and metacognition awareness. Furthermore, Muhali (2018) reveals that implementation of the reflective-metacognition learning model can consistently improve metacognition awareness, yet the impact towards metacognition knowledge and metacognition skill is stated inconsistent. Those studies show that inquiry-based learning empirically can improve metacognition knowledge and awareness, but no specific study examines the consistency of the impact of applying inquiry learning model towards metacognition knowledge and awareness.

In line with the earlier explanation, the impact of inquiry learning model by referring to the results of this study was found significantly different to metacognition knowledge of prospective teachers from three experimental groups, while metacognition awareness of students in Group B and Group C were not significantly different. These results indicate that the inquiry learning model does not have consistent impact to the increase of metacognition knowledge and metacognition awareness of prospective teachers' at IKIP Mataram. In genereal, metacognition knowledge was found significantly different in all three subject groups. The difference is addressed to subjects' ability, especially in their declarative knowledge. Declarative knowledge is seen as an epistemological understanding or understanding towards thinking and students' knowledge in general (Kuhn \& Dean, 2004) - is knowledge about skills, intellectual resources, and students' abilities (Schraw \& Dennison, 1994) and factors that influence one's performance (Schraw, 2006) to be employed to solve problems (Muhali, 2018). Different declarative knowledge has different effects too in applying the knowledge to solve problems (procedural). Procedural knowledge refers to one's own knowledge or beliefs towards given assignment. Someone has a aptitude of self-perception on how to do something (Rompayom et al., 2010) by involving awareness and management of cognition, including knowledge about strategies (Cross \& Paris, 1988; Kuhn \& Dean, 2004; Schraw, 2006). The self-perception aptitude deals with knowledge on how to use thoughts and strategies, knowledge on students' learning capacity (size), and types of strategies to be used (Downing, 2009; Gleitman, 1985; Weinert \& Kluwe, 1987; Muhali, 2018). In addition, students' confidence in their declarative knowledge and procedural knowledge is highly depended on conditional knowledge they have since it deals with accuracy in using the declarative knowledge that is in line with context of problem to be be solved. 
Different achievement in metacognition knowledge shown by prospective teachers is also influenced by their ability to regulate their cognition. Good metacognition knowledge is highly depended on their abilities in regulating cognition, especially IMS, $\mathrm{M}, \mathrm{D}$, and E. Low declarative knowledge resulted by the subjects causes low ability in information management strategies. Schraw and Dennison (1994) explain that one's ability in information management contributes to the quality of problem-solving. Information management in this study is students' ability to receive, store, organize or process, monitor, and select information to be used in solving problems. Muhali (2018) explains that awareness in terms of information management is alertness and focus to find, interpret, and ask the relevance of new information towards prior knowledge. Schraw (2006) explains that information management affects students' ability to monitor the process of problem solving. In line with this view, Nur (2011); Eggen and Kauchak (2012) state that information management involves an ability to select, use, and monitor learning strategies that are compatible with learning styles and situations encountered in order to find evidences of learning progress. Yurt et al (2015) found that learning styles mostly display a positive correlation with the motivated strategies for learning. The students' motivation and learning strategy scores exhibit significant variation according to their learning styles.

Other influential aspects that make differences are abilities to evaluate the use of information and strategies within the process of solving the problems. The abilities to manage knowledge as information, monitor, and conduct adequate evaluation have an impact on students' ability to repair mistakes of using information and strategies in order to achieve solutions for sophisticating problem solving (debugging), which is a strategy of repairing misunderstanding and performance (Schraw \& Dennison, 1994). Brown and DeLoache (1978) state that regulation of metacognition refers to mental activities conducted to regulate cognition strategies in an attempt to solve problems encountered. Fernandez-Duque et al., (2000) term this as identification of mistake for debugging that is a continuous control of students during learning process that is useful for them in identifying problems and altering the needs for learning, such as problem solving strategies whenever necessary (Jacobse \& Harskamp, 2012).

Based on the results and discussion that have been forwarded, it is necessary to give emphasis on the role of declarative knowledge within the steps of inquiry learning model that may assist possible construction of components that build comprehensive metacognition awareness within contextual problem offers. Therefore, it forces prospective teachers to explore consciously an in depth knowledge.

\section{CONCLUSION}

By referring the results and discussion of this study, it could be concluded that the inquiry learning model was considered effective to increase students' metacognition knowledge and awareness. Result of measuring Group A subjects' metacognition knowledge, by calculating their average score, found score of $n$-gain of 0.71 , in which improvements was found high. Group B and Group C recorded 0.66 and 0.63 , improved at moderate level. Results of this statistical calculation showed that there were significant differences of metacognition knowledge in prospective teachers before and 
after learning $(\mathrm{p}<0.05)$. The prospective teachers' metacognition awareness in all groups, based on average score of n-gain, was declared improve at moderate level. Results of the prospective teachers' metacognition awareness test also showed that there were significant differences of metacognition awareness scored by prospective teachers before and after learning ( $p<0.05)$. Results of calculating the impact of applying inquiry learning model towards prospective teachers' metacognition knowledge showed significant difference $(p<0.05)$ by students in all experimental groups. However, consistent impact after applying inquiry learning model was only showed in the score of metacognition awareness of Group B and Group C ( $p>0.05)$. These results indicate that inquiry learning model did not give consistent impact towards prospective teachers' metacognition knowledge and metacognition awareness.

\section{RECOMMENDATION}

It is found necessary to develop a learning model by making the inquiry learning model as a specific basic model emphasizing on students to carry out maximally the process of regulation of cognition, especially towards the aspects of IMS, M, E, and D. This should be conducted through integration of possible strategies, such as cognitive conflict, nonroutine concept presentation, or implementing portfolio-based performance. On the other hand, students generally could not make generalization of statements towards MAI items to be suitable with the actual awareness. Therefore, it is essential to develop instruments for metacognition awareness from the perspectives of domestic (local) customs and culture.

\section{REFERENCES}

Aiken, L. R. (1982). Psychological testing and assessment (4 ${ }^{\text {th }}$ edt.). Boston: Allyn \& Bacon.

Arends, R. (2012). Learning to Teach. Ninth Edition. New York: McGraw-Hill.

Artayasa, I P. Susilo, H., Lestari, U., \& Indriwati, S. E. (2018). The Effect of Three Levels of Inquiry on the Improvement of Science Concept Understanding of Elementary School Teacher Candidates. International Journal of Instruction, 11(2), 235-248.

Asy'ari, M., Ikhsan, M., \& Muhali. (2018). Validitas instrumen karakterisasi kemampuan metakognisi mahasiswa calon guru fisika. Prisma Sains: Jurnal Pengkajian Ilmu dan Pembelajaran Matematika dan IPA IKIP Mataram, 6(1), 18-26.

Brown, A. L., \& DeLoache, J. S. (1978). Skills, plans, and self-regulation. In R. Sieger (Ed.) Children's thinking: What develops? Hillsdale, NJ: LawrenceErlbaum Associates.

Cavanaugh, J. C., \& Perlmutter, M. (1982). Metamemory: A critical review. Child Development, 53, 11-28.

Cross, D. R., \& Paris, S. G. (1988). Developmental and instructional analyses of children's metacognition and reading comprehension. Journal of Educational Psychology, 80(2), 131-142. 
Downing, K. J. (2009). Self-efficacy and metacognitive development. The international journal of learning, 16(4), 187-199.

Eggen, P., \& Kauchak, D. (2012). Strategi dan model pembelajaran. Jakarta: Indeks.

Feiz, J.P. (2016). Metacognitive awareness and attitudes toward foreign language learning in the EFL context of Turkey. Procedia-Social and Behavioral Sciences. 232 (2016), 459-470.

Fernandez-Duque, D., Baird, J.A., \& Posner, M.I. (2000). Executive attention and metacognitive regulation. Consciousness and Cognition, 9, 288-307.

Flavell, J. H. (1971). First discussant's comments: What is memory development the development of? Human Development, 14 (2), 272-278.

Flavell, J. H. (1979). Metacognition and cognitive monitoring: a new area of cognitivedevelopmentan inquiry. American Psychologist, 34(10), 906-911.

Fraenkel, J., Wallen, N., \& Hyun, H. (2012). How to design and evaluate research in education ( $8^{\text {th }}$ edt.). New York: McGram-Hill Companies: Inc.

Fuad, N.M., Zubaidah, S., Mahanal, S., \& Suarsini, E. (2017). Improving Junior High Schools' Critical Thinking Skills Based on Test Three Different Models of Learning. International Journal of Instruction, 10(1), 101-116.

Goodwin, J. (2012). SAGE Biographical Research. LA, US: SAGE Publications.

Hake, R. R. (1999). Analyzing Change/Gain Score. [Online]. Retrived from: http://www.physics.indiana.edu/sdi/AnalizingChange-Gain.pdf.

Hussain, A., Azeem, M., \& Shakoor, A. (2011). Physics Teaching Methods: Scientific Inquiry Vs Traditional Lecture. International Journal of Humanities and Social Science, 1(19), 269-276.

Jacobs, J., \& Paris, S. (1987). Children's metacognition about reading. Issues in definition, measurement, and instruction. Educational Psychologist, 22, 255-278.

Jacobse, A. E., \& Harskamp, E.G. (2012). Towards efficient measurement of metacognition in mathematical problem solving. Metacognition Learning, 7(1), 133149.

Kizkapan, O \& Bektas, O. (2017). The Effect of Project Based Learning on Seventh Grade Students' Academic Achievement. International Journal of Instruction, 10(1), 37-54.

Kluwe, R. H. (1982). Cobnitive knowledge and executive control: Metacognition. Springer, 21(1), 201-224.

Kluwe, R. H. (1987). Executive decisions and regulation of problem solving behavior. In F. E. Weinert \& R. H. Kluwe (Eds.), Metacognition, motivation, and understanding (pp. 31-64). New Jersey: Lawrence Erlbaum Associates, Inc. 
Kuhlthau \& Todd. 2007. Guided Inquiry: A framework for learning through school librariesin 21 st century schools. New Jersey: CISSL.

Kuhn, D. \& Dean, D. (2004). A bridge between cognitive psychology and educational practice. Theory into Practice, 43(4), 268-273.

Lai, E. R. (2011). Metacognition: A literature review. Research Report (pp. 1-41). Pearson. Retrived from http://www.pearsonassessments.com.

Lee, M. (2006). What does constructivism suggest for science education. Northridge: California State University.

Margaret, M. W. (2002). Metacognition. Singapore: Thomson Learning, Inc.

McCormick, C. B. (2003). Metacognition and learning. In W. M. Reynolds \& G. E. Miller (Eds.), Handbook of psychology: Educational psychology (pp. 79-102). Hoboken: Wiley.

Meijer, J., Veenman, M.P.J. \& Wolters. (2006). Metacognitive activities in textstudying and problem-solving: Development of a taxonomy. Educational Research and Evaluation, (12)3, 209-237.

Muhali. (2018). Pengembangan Model Pembelajaran Reflektif-Metakognitif untuk Meningkatkan Kemampuan Metakognisi Siswa SMA [Depelovement of reflectivemetacognitive learning model to improve senior high school students' metacognition ability]. Doctoral Disertation. Universitas Negeri Surabaya.

Niedringhaus, K. L. (2010). Teaching Better Research Skills by Teaching Metacognitive Ability. Winter/Spring, 18(2), 113-118.

Oz, H. (2016). Metacognitive awareness and academic motivation: a crosssectional study in teacher education context of Turkey. Procedia-Social and Behavioral Sciences. 232 (2016), 109-121.

Paris, S. G. \& Winograd, P. (1990). How metacogniton can promote academic learning and instruction. Hillsdale: Lawrence Erlbaum.

Pintrich, P. R., Wolters, C., \& Baxter, G. (2000). Assessing metacognition and selfregulated learning. In G. Schraw \& J. Impara (Eds.), Issues in the measurement of metacognition (pp. 43-97). Lincoln, NE: University of Nebraska-Lincoln.

Prayogi, S., Yuanita, L., \& Wasis. (2018). Critical Inquiry Based Learning: A Model of Learning to Promote Critical Thinking Among Prospective Teachers of Physic. Journal of Turkish Science Education, 15(1), 43-56.

Pressley, M., \& Harris, K. R. (2006). Cognitive strategy instruction: From basic research to classroom instruction. In P. Alexander \& P. Winne (Eds.), Handbook of educational psychology (2nd ed., pp. 265-286). San Diego: Academic.

Rompayom, P., Tambunchong, C., Wongyounoi, S. \& Dechsri, P. (2010). The development of metacognitive inventory to measure students' metacognitive knowledge 
related to chemical bonding conceptions. Paper presented at International Association for Educational Assessment (pp. 1-7). Thailand: IAEA Thailand.

Schraw, G. \& Dennison, R. S. (1994). Assessing metacognitive awareness. Contemporary Educational Psychology. 19(1), 460-475.

Schraw, G. (2006). Knowledge: Structures and processes. In P. Alexander \& P. Winne (Eds.), Handbook of educational psychology (2nd ed., pp. 245-264). San Diego: Academic.

Schraw, G., \& Moshman, D. (1995). Metacognitive theories. Educational Psychology Review, 7(4), 351-371.

Schraw, G., Olafson, L., Weibel, M., \& Sewing, D. (2012). Metacognitive Knowledge and Field-based Science Learning in an Outdoor Environmental Education Program. In A. Zohar \& Y.J. Dori (Eds.), Metacognition in Science Education, Trends in Current Research, Contemporary Trends and Issues in Science Education. (pp. 57-77). New York: Springer.

Senomoglu, N. (2009). Gelisim ögrenme ve ögretim [Evolution, learning and teaching]. Ankara: Gazi Kitabevi.

Seraphin, K. D., Philippoff, J., Kaupp, L., \& Vallin, L. M. (2012). Metacognition as means to increase the effectiveness of inquiry-based science education. Science Education International. 23(4), 366-382.

Sternberg, R. J. (1990). Metaphors of the mind: Conceptions of the nature of intelligence. Cambridge: Cambridge University Press.

Suardana, I N., Redhana, I W., Sudiatmika, A. A. I. A. R., \& Selamat, I N. (2018). Students' Critical Thinking Skills in Chemistry Learning Using Local Culture-Based 7E Learning Cycle Model. International Journal of Instruction, 11(2), 399-412.

Sukaisih, R., \& Muhali. (2014). Meningkatkan kesadaran metakognitif dan hasil belajar siswa melalui penerapan pembelajaran problem solving. Prisma Sains: Jurnal Pengkajian Ilmu dan Pembelajaran Matematika dan IPA IKIP Mataram, 2(1), 71-82.

Thomas, G. P. (2012). Metacognition in science education: Past, present and future considerations. In G.J. Fraser, K. G. Tobin, C. J. McRobbie (Eds.) Second international handbook of science educations, (pp. 131-144). New York: Springer.

Tosun, C., \& Senocak, E. (2013). The effects of problem-based learning on metacognitive awareness and attitudes toward chemistry of prospective teachers with different academic backgrounds. Australian Journal of Teacher Education, 38(3), 6173.

Veenman, M. V. J., \& Spaans, M. A. (2005). Relation between intellectual and metacognitive skills: Age and task differences. Learning and Individual Differences, 15(1), 159-176. 
Veenman, M. V. J., Meijer, J., Wolters, V. H., \& Afflerbach, P. (2006). Metacognition and learning: Conceptual and methodological considerations. Springer, 1, 3-14.

Veenman, M. V. J., Wilhelm, P., \& Beishuizen, J. J. (2004). The relation between intellectual and metacognitive skills from a developmental perspective. Learning and Instruction, 14(1), 89-109.

Veenman, M.V.J. (2012). Metacognition in science education: definitions consituents, and their intricate relation with cognition. In A. Zohar \& Y. J. Dori (Eds.), Metacognition in science education (pp. 21-36). London: Springer.

Weinert, F. E. \& Kluwe, R. H. (1987) Metacognition, motivation and understanding. Hillsdale, NJ: Erlbaum.

Ya-Hui, W. (2012). A Study on Metacognition of College Teachers. The Journal of Human Resource and Adult Learning, 8(1), 84-9.

Yuliati, L., Riantoni, C. \& Mufti, N. (2018). Problem Solving Skills on Direct Current Electricity through Inquiry-Based Learning with PhET Simulations. International Journal of Instruction, 11(4), 123-138.

Yurt, E., Aydin, M., \& Sahin, I. (2015). Assessing uses of motivated strategies by middle school students based on their learning styles. Croatian Journal of Education, 17(3), 117-149.

Yusnaeni, Corebima, A. D., Susilo, H. \& Zubaidah, S. (2017). Creative Thinking of Low Academic Student Undergoing Search Solve Create and Share Learning Integrated with Metacognitive Strategy. International Journal of Instruction, 10(2), 245-262.

Zohar, A., \& David, A. B. (2008). Explicit teaching of meta-strategic knowledge in authentic classroom situations. Metacogniton and Learning, 3(1), 59-82.

Zohar, A., \& David, A. B. (2009). Contribution pf meta-strategic knowledge to scientific inquiry learning. ERIC: International Journal of Science Education, 31(12), $1657-1682$. 